\title{
Grounded Theory for Implementation of Labor Policy Women Disability Research
}

\author{
${ }^{1}$ Na'ilatul Muinah Audiyah, ${ }^{2}$ Fadillah Putra, ${ }^{3}$ Wike \\ ${ }^{1}$ Master of Gender Studies, Universitas Brawijaya, Malang, Indonesia \\ ${ }^{2}$ Faculty of Administrative Science, Universitas Brawijaya, Malang, Indonesia \\ ${ }^{3}$ Faculty of Administrative Science, Universitas Brawijaya, Malang, Indonesia
}

\begin{abstract}
Implementation of employment policies for women with disabilities using grounded theory, because researchers assume that the method, can reveal the problem in this study, namely how the views and impacts of the implementation of employment policies for women with disabilities, especially those in Malang City. This study uses the qualitative approach of the Straussian version of the grounded theory method. Because Straussian tends to be more structured, it requires several rules and is complex so that it is open to various kinds of form the initial categories along with sub categories based on information extracted from the phenomenon.
\end{abstract}

Keywords: Grounded Theory, Women Disability, Female Worker, Policy Implementation

\section{Research Background}

Methods in research that change from time to time, so that they can change in the course of the journey thus becoming the main exponent that contradicts or differences in viewpoints on certain aspects. This happened to the early originators of grounded theory, namely Barney Glaser and Anselm Strauss, so that it appeared today was the term Strauss and Glaser grounded theory model. The difference in views between the second exponent of grounded theory lies in the process of data analysis, specifically the procedure used. Coding Process in grounded theory is the process of analyzing data that involves researchers in the process of exploration, intervention and data conceptualization.

Especially Straussian - Glaserian, both of them use coding processes but in different presentation procedures. At the operational level, the coding method in Glaser is simpler, the focus is still adhering to the original version of grounded theory. Glaser divides the coding process in two procedures, namely subtantive coding and theoretical coding. Subtantive coding

\footnotetext{
* Corresponding author: Na'ilatul Muinah Audiyah nailatulmuinahaudiyah@gmail.com

Published online at http://IJDS.ub.ac.id/

Copyright $\odot 2019$ PSLD UB Publishing. All Rights Reserved
}

consists of two phases, namely open coding and selective coding. Open coding is an activity to form the initial categories along with sub categories based on information extracted from the phenomenon.

In these categories compiled using constant and memo comparisons. The results of this stage will guide researchers to take the next sample through theoretical samples. For the next stage, selective coding is a systematic selection by making categories that are more conceptual or focused by using constant comparative methods and memo.

The process is carried out continuously until it finds a point of saturation, meaning that no other categories can be formed. Then the categories are sorted and confirmed with relevant literature. The Glaserian version of grounded theory provides space for in-depth identification of terms that are rarely referred to by participants who are considered relevant and have strong meanings for a study, so that whether or not the term participant must determine the power to be classified in the category.

In the substantive arena research has a very important position to be able to guide researchers to focus on the research objectives. The final 
product of grounded theory is propositions that are ready to be verified and tested at the next stage of research. Glaser explained the importance of the relationship between coding processes, data and theory.

The view is different from Anselm Strauss's meaning by dividing coding into three stages, namely, open coding, axial coding and selective coding. Each stage of the process is increasingly complex and detailed. Strauss opens up space for the entry of a lot of information that is not necessarily relevant to the purpose of initial research. Therefore axial coding must be done by increasingly focusing on each category based on labels that often arise from participants.

The longer the procedure the more complex and detailed the results obtained. Wenglensky and Jing (2010) state that the workings of three types of coding are not always sequential, they tend to overlap. After collecting additional data, the researchers began to return to analyzing and coding the data, and using the results of the various analysis and coding processes to function formulate the next analysis process.

Strauss modified the grounded theory in a more structured model of data collection and data analysis. This method is more appropriate to be used to construct theory because it involves data openness. The Straussian Grounded theory refers to the poststructuralist paradigm with the view of constructivist social ontology.

The fundamental difference between Glaser and Strauss is on the open coding and axial coding aspects where Glaser places the open coding stage as substantive coding, while for Strauss occupies this stage independently. In addition, Strauss also added the axial coding stage as a consequence of opening information and prioritizing labels that often appear. The Strauss Grounded Theory method tends to be more structured, requires several rules and is complex because of the openness to various kinds of information (Maharani, 2014; Kamayanti, 2016; Sukidin, 2002; Bandur, 2016; Bungin, 2015; Cresswell, 2017).

Therefore, in the study of the implementation of employment policies for women with disabilities using grounded theory, because researchers assume that the method, can reveal the problem in this study, namely how the views and impacts of the implementation of employment policies for women with disabilities, especially those in Malang City.

\section{Research Methodology}

This study uses the qualitative approach of the Straussian version of the grounded theory method. Because Straussian tends to be more structured, it requires several rules and is complex so that it is open to various kinds of information. In accordance with the purpose of the study, namely to explore and describe the views and the impact of the implementation of labor policies for women with disabilities.

The selection of participants through the sampling technique used in this research is Purposive Sampling, which determines the sample that matches the research objectives through the characteristics of the sample because the process of coding and data analysis may be subject to distortion because at this stage researchers will select several research subjects stand out and represent decision-making behaviors in the implementation of employment policies for women with disabilities.

The process of collecting research participants, researchers assisted by other informants by using Snowball Sampling, namely the way informants were found to be willing to refer researchers to other informants (Bungin, 2015). The participants were as many as 10 people, with women totaling 6 people and 4 men. Disabled participants of 4 people consisted of 3 women and 1 male, as well as 5 government informants and 5 companies that received 1 person with disabilities.

\section{Results and Discussion 3.1 Results}

When analyzing the data, the process begins with the researcher, namely the open coding process which is part of the data analysis, where the researcher identifies, names, categorizes and decomposes the symptoms found in the text of the results of interviews, observations, and researchers' diary. The results of the transcript researcher interview will be as empirical research data, from which researchers coding lines by line to be able to help researchers identify the intent of what was conveyed by participants

Tabel 1. The results of open coding

\begin{tabular}{|ll|} 
- Rated by a defective & - Survive for life \\
system & - Financial difficulties \\
- Loss of system & - Facing challenges for life's \\
- Emphasized by the system & well-being \\
- Covered with fear & - Trapped at home \\
- Envy witnesses the & - Loss of confidence in \\
struggle of others & yourself \\
- Labeled as a beggar & \\
\hline
\end{tabular}




\begin{tabular}{|lc|}
\hline - Ignorance & - Eliminating stigmatized \\
- Appreciated as a useless & identity \\
person & \\
- Suffering from persecution & \\
\hline
\end{tabular}

After doing open coding and producing sub-categories from empirical. The next step that researchers do is axial coding, in this process researchers connect between sub-categories that researchers can from the results of the open coding process into a category. This process is aided by coding paradigm, where researchers connect existing theories relating sub-categories into a conceptual category. In this process researchers need time and again to be able to find relationships, the repetition process is carried out repeatedly by researchers as constant comparison between indicators, codes, concept categories to be able to produce new empirical.

Tabel 2. The Result of axial coding

\begin{tabular}{|c|c|}
\hline Categories & Sub-Categories \\
\hline \multirow{2}{*}{$\begin{array}{l}\text { Doing something } \\
\text { that is of no use }\end{array}$} & Rated by a defective system \\
\hline & Loss of trust in the system \\
\hline \multirow{3}{*}{$\begin{array}{l}\text { Feelings of stress } \\
\text { and fear of policy }\end{array}$} & Emphasized by the system \\
\hline & Covered with fear \\
\hline & Envy witnesses the struggle of others \\
\hline \multirow{3}{*}{$\begin{array}{l}\text { Existence in public } \\
\text { view }\end{array}$} & Labeled as a beggar \\
\hline & Ignorance \\
\hline & Appreciated as a useless person \\
\hline \multirow{2}{*}{$\begin{array}{l}\text { Facing } \\
\text { discrimination and } \\
\text { intimidation }\end{array}$} & Suffering from persecution \\
\hline & Survive for life \\
\hline \multirow{3}{*}{$\begin{array}{l}\text { Lack of health, } \\
\text { physical and mental } \\
\text { resources }\end{array}$} & Financial difficulties \\
\hline & Facing challenges for self-welfare \\
\hline & Trapped at home \\
\hline \multirow{2}{*}{$\begin{array}{l}\text { Become a different } \\
\text { person }\end{array}$} & Loss of confidence in yourself \\
\hline & Eliminating stigmatized identity \\
\hline
\end{tabular}

Next, the open coding and axial coding process carried out by researchers is selective coding where researchers find relations between each category and sub-category to produce research themes.

Tabel 3. The result of selective coding

\begin{tabular}{|c|c|}
\hline Theme & Categories \\
\hline \multirow{2}{*}{$\begin{array}{l}\text { Policy that is not yet } \\
\text { wise }\end{array}$} & Doing something that is of no use \\
\hline & Feelings of stress and fear of policy \\
\hline \multirow{2}{*}{$\begin{array}{l}\text { Dual discrimination } \\
\text { for women with } \\
\text { disabilities }\end{array}$} & Existence in public view \\
\hline & $\begin{array}{l}\text { Facing discrimination and } \\
\text { intimidation }\end{array}$ \\
\hline \multirow{2}{*}{$\begin{array}{l}\text { Psychological } \\
\text { women with } \\
\text { disabilities working }\end{array}$} & $\begin{array}{l}\text { Lack of health, physical and mental } \\
\text { resources }\end{array}$ \\
\hline & Become a different person \\
\hline
\end{tabular}

\subsection{Discussion}

This study explains that in the implementation of labor policies there are categories that represent women with disabilities including unwise policies, dual discrimination for women with disabilities, and psychological disabilities for women working.

\subsubsection{Policy that is not yet wise}

In this pattern what is felt for policy implementers and recipients of the policy has not been felt maximally, it is explained that there is a grouping that existing policies are assessed as a defective system where the policy implementers themselves only conduct programs in accordance with the instructions of the supervisor so that the work program is considered fulfilled and forced already disability responsive

For policy implementers themselves, there are those who understand how they should act, and some do not understand what programs they must do. Knowledge of information related to work programs should be understood by all work implementers. Finally there are disparities in communication relations between what policy recipients want and policy implementers.

It is considered important that the recipient of the policy loses a sense of trust in the system. Where it was assumed that the regulations applied had no benefits for them, it was impressed that the regulation was forced to exist. All activities related to disability are only limited to work programs, there is no follow-up in the future.

Compliance and respect for the recipient of the policy on a policy that is implemented is quite good, but morally they realize that the policies that have been implemented have not fulfilled what they expected. Feelings of stress and fear of policies implemented, illustrated where the executor of the policy in a company must meet the quota set by the central leadership no more or less in accepting disability employees as if the system must be done. Or do not have to accept disability employees.

There is a good benefit that the system is running where to be able to prosper the disabled, but making a policy as if it is a dependency does not make the disabled become independent, for example, because the government program for 
disabled persons is finally programmed. Come to get transportation funds so on but the benefits of the program are felt to be less effective only limited to participation.

Implementers of policies to provide disability employee reception services have not reached a meeting point because they are trapped in having to change the facilities they have to be accessible to persons with disabilities. Finally, the grouping of who is acceptable to work, whose facilities are not much change, is just an example, for example Deaf do not need communication tools but can do all activities like the others.

While there are many differences felt by persons with disabilities, a human nature wants to be like everyone else to get recognition of their presence, facilities and opportunities. The community system should have no difference in assessing certain groups.

\subsubsection{Dual Discrimination For Women With Disabilities}

The results of the data explain the stereotype for persons with disabilities that they are considered beggars, on the other hand disability does not want to get compassion. They expect to be valued and helped to live independently even with small businesses. Because of their disability they are able to live like others. The view of disability makes it difficult for women with disabilities to get decent jobs, must prove to recipients of disabilities that they are capable. Positive environmental support from around is striking on women with disabilities.

\subsubsection{Psychological Women With Disabilities Working}

The view that underestimates disability that is rooted in the current situation of the community, there are those who feel concerned that there are also those who do not care because they feel disgusted with disabilities. These disparaging views are what make disability not yet recognized in their capacity in the community.

Assessment as a useless person results in the difficulty of persons with disabilities seeking welfare. The challenge they have to face is to be considered capable, namely trying to change people's views on their presence. The intimidation and discrimination they have to feel depends on the disability they have. Because each disability struggle for life will be different.

Financial needs are needed for persons with disabilities due to fulfillment of life. For women with disabilities getting jobs makes them able to mingle with others. Not troubling the family is the desire of the disabled people not only to stay at home but to be useful for the people around them. Become an independent person.

\section{Conclusion}

The neglect of human values that become social construction has an impact on how people perceive persons with disabilities especially in women with disabilities, the gap in accessibility affects the community itself which disabilities persons, not persons with disabilities who disability them.

Even the life order which considers that women with disabilities need to be pitied affects the psychology of women with disabilities, because it becomes a label that they need to be pitied and become a doctrine that women with disabilities are useless.

Then the employment system that still views the physical becomes the main factor in the work, with the requirements must look attractive, physically and mentally healthy. Impact on the closure of space for persons with disabilities. Therefore the tendency of our society which is "apathetic" towards policy programs that view persons with disabilities is only charity. So that it does not empower people with disabilities to be able to be involved in various social relations.

\section{References}

ADD. (2015). How to Ensure No One Is Left Behind: Why Disability Inclusive Development Programming Is Good For Development. Independence, Equality, Opportunity For Disabled people Living In Poverty

Agustino, L. (2017). Dasar-dasar Kebijakan Publik (Edisi Revisi). Bandung: Alfabeta.

Andriani, Nurul Saadah. (2016). Kebijakan Responsif Disabilitas: Pengarusutmaan Managemen Kebijakan Level Daerah, Nasional, dan Internasional. Jurnal Palastren, Vol. 9 No. 1

Bandur, Agustinus. (2016). Penelitian Kualitatif: Metodologi, Desain, dan Teknik Analisis Data 
dengan Nvivo 11 Plus. Jakarta: Mitra Wacana Media

Bungin, M. Burhan. (2015). Penelitian Kualitatif: Komunikasi, Ekonomi, Kebijakan Publik, dan Ilmu Sosial Lainnya. Edisi Kedua. Jakarta: Prenada Media Group

Budiasih, I Gusti. (2014). Metode Grounded theory dalam Penelitian Kualitatif. Jurnal Ilmiah Akuntansi dan Bisnis, Vol. 9 No. 1

Creswell John W. (2017). Research Design Pendekatan Metode Kualitatif, Kuantitatif, dan Campuran. Yogyakarta: Pustaka Pelajar.

Devandas, Aguilar C. (2017). Social Protection and Person with Disabilities. International Social Security Review Vol 70 No 4

Fakih M. (2012). Analisis Gender \& Transformasi Sosial. Yogyakarta: Pustaka Pelajar

Lianawati, Ester \& Merdekawati, Pricilia. (2009). Konsep Kesejahteraan Psikologis Pada Perempuan Asmat (Studi Pada Perempuan Asmat di Timika). Jurnal Proceding PESAT, Vol. 3

Narwoko, J. Dwi.,\& Suyanto, Bagong.(2004). Sosiologi Teks Pengantar Dan Terapan (Edisi Pertama). Jakarta: Prenada Media.

Nurani, Farida. (2017). Buruh Migran Perempuan: Afirmasi Kebijakan Bagi Kaum Marginal. Malang: UB Press

Saptari, Ratna.,\& Holzner, Brigitte. (2016). Perempuan, Kerja Dan Perubahan Sosial (Sebuah Pengantar Studi Perempuan). Jakarta: Kalyanamitra.

Tanahitumesseng, Yonna Eunnika. (2017). Makna Menstruasi Bagi Perempuan Suku Naulu-Dusun Rohua Kabupaten Maluku Tengah Provinsi Malaku. Tesis. Program Magister Kajian Wanita. Universitas Brawijaya

Thohari, Slamet. (2017) Sudah Difabel, Perempuan Pula. Jawa Pos Bulan Desember

Haryanto, S. (2012). Spektrum Teori Sosial: Dari Klasik Hingga Postmodern. Yogyakarta: Ar-Ruzz Media.
ILO. (2011). Mempromosikan Pekerjaan Layak Bagi Semua Orang: Membuka Kesempatan Pelatihan dan Kerja Bagi Penyandang Disabilitas. Reader Kit

ILO. (2013). Pedoman ILO Tentang Pengelolaan Penyandang Disabilitas Di Tempat Kerja

ILO. (2003). Strategi Pengarusutamaan Gender: ILO Jakarta 2003-2005

Liliweri, A. (2014). Sosiologi \& Komunikasi Organisasi. Jakarta: Bumi Aksara.

Jones Doug. (2007). Domestic Violence Against Women With Disabilities: A Feminist Legal Theory Analysis.Florida A \& M University Law Review Article 6 Vol 2 No 1

Jones, N., Marshall, Elizabeth P.,\& Stavropoulou, M.,. (2018). Adolescents With Disabilities: Enhancing Reselience and Delivering Inclusive Development. Gender and Adolescence: Global Evidence (GAGE)

Poerwanti, S. D. (2017). Pengelolaan Tenaga Kerja Difabel untuk Mewujudkan Workplace Inclusion. INKLUSI: Journal of Disability Studies Vol. 4, No. 1, 1-24.

Tigayanti, Erna., Soeaidy, M. Saleh., \& Nurpratiwi, R. (2014). Implementasi Kebijakan Pengarusutamaan Gender (PUG) Bidang Pendidikan di Kota Malang (Studi Kasus SMA 8 Malang). Jurnal Wacana Vol. 17, No. 4

Rahayu, W. K. (2016). Analisis Pengarusutamaan gender dalam Kebijakan Publik (Studi Kasus dalam Kebijakan Publik (Studi Kasus di BP3AKB Provinsi Jawa Tengah). Jurnal Analisis dan Pelayanan Publik Vol 2 No 1

Saffer, Jessica. (2017) Responses of People with Physical Health Conditions to Change in Disability Benefits:A Grounded Theory Study. Disertasi:University of Hertfordshire.

Morrison, J.,Basnet, M., Budhathoki, B., Adhikari, D., Tumbahangphe, K., Manandhar, D., Costello, A., \& Groce, N.,. (2014). Disabled Women's Maternal And Newborn Health Care In Rural Nepal: A Qualitative Study. Midwifery, 1132-1139 
Utaminingsih, A. (2017). Gender dan Wanita Karir. Malang:UB Press

UU No. 13 tahun 2003 Tentang Ketenagakerjaan

Muashomah. (2010). Analisis Labelling Perempuan Dengan teori Feminisme Psikoanalisis:Studi Kasus Majalah Remaja Olga. Jurnal Komunikasi 2 (2), 143-155

Subiyantoro, E. B. (2005). Sensitivitas gender Kebijakan Pemerintahan SBY. Policy Assesment. The Indonesian Institute

Sukesi Keppi. (2015). Gender dan kemiskinan Di Indonesia. Malang:UB Press.

Sukidin Basrowi. (2002). Metode Penelitian Kualitatif Perspektif Mikro. Surabaya: Insan Cendekia.

Kusumasari, B. (2014). Manajemen Bencana dan Kapabilitas Pemerintah Lokal. Yogyakarta: Gava Media

Kamayanti Ari. (2016). Metodologi Penelitian Kualitatif Akuntansi Pengantar Religiositas Keilmuan. Jakarta: Yayasan Rumah Peneleh.

Putra, Fadillah. (2018). Interrogating The Role Of Democracy In Providing Social Policis For People With Disabilities: Insights From Southeast Asia. Indonesian Journal Of Disability Studies (IJDS).2018:Vol.5(2):PP222-231.

Yusuf A. Muri. (2015). Metode Penelitian Kuantitatif, Kualitatif \& Penelitian Gabungan. Jakarta:Prenadamedia Group

Waskito, J., \& Irawati, H. (2007). Perbedaan Gender dan Sikap Terhadap Peran Pekerjaan Keluarga: Implikasinya Pada Pengembangan Karir Wanita. Jurnal Manajemen dan Bisnis Universitas Muhammadiyah Surakarta

Wike, (2015). Mother's Perspective On Service Delivery For Children With Autism In Regional Indonesia City.Disertasi: University of Canberra

Peraturan Menteri Negara Pemberdayaan Perempuan dan Perlindungan Anak Republik Indonesia Nomor 08 Tahun 2010 : Pedoman Perencanaan dan Penganggaran Responsif
Gender Bidang Ketenagakerjaan Dan Ketransmigrasian

Parker, Grebe, Hirst, Hendey, Pascall. (2007). Double Discrimination? Gender and Disability in Access To The Labour Market. Social Policy Research Unit: University Of York

Kiani, S. (2009). Women With Disabilities in The North West Province of Cameroon: Resilient and Deserving of Greater Attention. Disability \& Society Vol. 24 No. 4, 517-531

Naraharisetti, R., \& Castro, Marcia C. (2016). Factors Associated with Persons with Disability Employment in India: a Cross Sectional Study. BMC Public Health 16:1063

Cramm, J.M, \& Finkenflugel, H. (2008). Exclusion Of Disabled People From Microcredit In Africa And Asia: A Literature Study. Asia Pacific Disability Rehabilitation Journal Vol 19 No. 2

Dewi, U. (2015). Implementasi Kebijakan Kouta Bagi Penyandang Disabilias Untuk Mendapatkan Pekerjaan Di Kota Yogyakarta. Jurnal Kajian Ilmu Administrasi Negara Vol 3 No. 2 Hal. 67-83

Nuraini. (2018). Catatan Pemerintah, Sebanyak 414.222 Penyandang Disabilitas Butuh Kerja. Https://jpp.go.id/humaniora/sosialbudaya/319416 diakses tanggal 16 Oktober 2018 jam 16.15

Maharani, Satia Nur. (2014). Perilaku Investor dalam pengambilan Keputusan Investasi di Pasar Modal: Analisis Glaserin Grounded Theory. Disertasi Fakultas Ekonomi dan Bisnis: Universitas Brawijaya 